University of Nebraska - Lincoln

DigitalCommons@University of Nebraska - Lincoln

Faculty Publications from the Harold W. Manter Laboratory of Parasitology

December 2005

\title{
Introduction of Gerardo Pérez-Ponce De León, the 2005 Henry Baldwin Ward Medalist
}

Scott Lyell Gardner

University of Nebraska - Lincoln, slg@unl.edu

Follow this and additional works at: https://digitalcommons.unl.edu/parasitologyfacpubs

Part of the Parasitology Commons

Gardner, Scott Lyell, "Introduction of Gerardo Pérez-Ponce De León, the 2005 Henry Baldwin Ward Medalist" (2005). Faculty Publications from the Harold W. Manter Laboratory of Parasitology. 17. https://digitalcommons.unl.edu/parasitologyfacpubs/17

This Article is brought to you for free and open access by the Parasitology, Harold W. Manter Laboratory of at DigitalCommons@University of Nebraska - Lincoln. It has been accepted for inclusion in Faculty Publications from the Harold W. Manter Laboratory of Parasitology by an authorized administrator of DigitalCommons@University of Nebraska - Lincoln. 


\title{
INTRODUCTION OF GERARDO PÉREZ-PONCE DE LEÓN, THE 2005 HENRY BALDWIN WARD MEDALIST
}

\author{
Scott L. Gardner \\ Harold W. Manter Laboratory of Parasitology, University of Nebraska-Lincoln, Lincoln, Nebraska 68588-0514.e-mail: slg@unl.edu
}

I have the incredibly great pleasure to introduce Dr. Gerardo Pérez-Ponce de León, the 2005 Henry Baldwin Ward Medalist of the American Society of Parasitologists.

Gerardo is one of the most gifted of the latest batch of researchers who uphold the great tradition of international collaboration and friendship between Mexican parasitologists and parasitologists in the United States. This all started in the early 1940s with the friendship that naturally developed between 2 internationally known giants on each side of the Rio Bravo, i.e., Eduardo Caballero y Caballero (founder of the Laboratorio de Helminthología at the Universidad National Autonóma de México (UNAM) and ostensibly the father of Mexican parasitology) and the venerable Harold Winfred Manter at the University of Nebraska.

After both Manter and Caballero passed on, the friendships and collaborations that had developed continued between Mary Lou Pritchard of the newly established Manter Laboratory of Parasitology at the University of Nebraska-Lincoln and Marguerita Bravo-Hollis and other researchers in the Laboratorio de Helminthología, Instituto de Biología, UNAM. Later, continuing the tradition of cross-border, cross-national collaborations, Daniel R. Brooks (also a Ward Medalist and former student of Dr. Pritchard), trained both Gerardo and his close friend, Virginia León-Régagnon, as postdoctoral associates at the University of Toronto, Department of Zoology.

The culmination of these collaborations that started long ago between 2 places as geographically dissimilar as southeastern Nebraska and México City, México, ultimately resulted in Gerardo working with us in the Manter Laboratory for a year during his most recent sabbatical in 1998-1999. His students are now fanning out into niches across North America, notably, Dr. Agustín Jiménez-Ruiz, who worked with me for his Ph.D., is now the Collection Manager of the Manter Laboratory. I am also privileged to work on various committees of students of the parasitologists at UNAM.

The point of this quick history is to show the real advantage of having communicative, outgoing, and stellar scientists in the American Society of Parasitologists. Gerardo Pérez-Ponce de León characterizes the true nature of parasitology as a collaborative and integrative discipline. He works with herpetologists, ichthyologists, mammalogists, biogeographers, and others who provide expertise on the hosts of the parasites that he is studying, for without detailed knowledge of the biology of the hosts, there would be no discipline of parasitology and without these collaborations our field of study would be much poorer. Gerardo works with all members of the global community of biologists to do parasitology.

Gerardo received his bachelor's degree in biology in 1986 from UNAM. During his undergraduate studies, he worked with Dr. Guillermo Salgado on digenetic trematodes, including species Posthodiplostomum. In 1989, he finished his Master of Science (emphasis-Biology) at UNAM under Dr. Rafael Lamothe Argumedo. In 1992, he earned his Doctorate in Sciences (Biología) from UNAM, working on the systematics of species of Posthodiplostomum. In April 1992, he was appointed Associate Researcher in the Instituto de Biología, UNAM. In 1996, he received tenure in the Instituto de Biología, UNAM, and in 2004 he was promoted to Full Professor in the Instituto de Biología, UNAM.

Gerardo is not new to receiving awards. In 1997, he won the Premio Nacional de Investicagión en Alimentos in the area, Aspectos de Frontera en Biología Animal, for his work entitled: "Estudio de la Helmintofauna del pescado blanco (Chirostoma estor) en el Lago de Pátzcuaro Michoacán.” In 2002 he was awarded an even more prestigious prize, the "Premio de Investigación en Ciencias Naturales" from the Academia Mexicana de Ciencias. The award was presented personally by $\mathrm{Sr}$. Vincente Fox, President of México.

In only $15 \mathrm{yr}$, Gerardo has published 77 papers in peer-reviewed journals, 6 chapters in books, 3 books, and several other publications. He has served as director of 8 undergraduate, 12 M.Sc., and 3 Ph.D. students. He currently supervises more than 6 other students, ranging from undergraduates to doctoral candidates. He is truly a collaborative parasitologist and has lectured in courses as varied as parasitology, zoology, field biology, taxonomy, helminthology, and phylogenetic systematics. That is not all. To support his work and that of his students, he has received grants in excess of $\$ 2,250,000$ in the past $15 \mathrm{yr}$ and he has made a difference in the lives of several hundred students at UNAM who have enrolled in zoology and parasitology courses. His research program is one of continuing collaboration and training of the next generation of parasitologists in taxonomy, systematics, and ecology, not only in Mexico, but globally.

Congratulations Dr. Gerardo Pérez-Ponce de León! Keep up the good work! If it was not for Hurricane Dennis, which cut short the annual meeting of the ASP in Mobile, Alabama, we would have heard the first acceptance speech from a member of the ASP who was from a country south of the U.S. border.

Good work, Gerardo!

Con un abrazo fuerte! 